\title{
Alburnite, $\mathrm{Ag}_{8} \mathrm{GeTe}_{2} \mathrm{~S}_{4}$, a new mineral species from the Roşia Montana Au-Ag epithermal deposit, Apuseni Mountains, Romania
}

\author{
CĂLIN G. TĂMAȘ ${ }^{1,2, *}$, BERNARd GROBETY ${ }^{2}$, LAURENT BAILLY ${ }^{3}$, HEINZ-JUERGEN BERNHARDT ${ }^{4}$ \\ AND ADRIAN MINUT ${ }^{5}$ \\ ${ }^{1}$ Department of Geology, University Babeş-Bolyai, 1, M. Kogălniceanu Street, 400084 Cluj-Napoca, Romania \\ ${ }^{2}$ Department of Geosciences, Fribourg University, 6 Avenue Musée, CH-1700 Fribourg, Switzerland \\ ${ }^{3}$ BRGM, Avenue Claude Guillemin, BP 36009, F-45060 Orléans, France \\ ${ }^{4}$ Institute of Geology, Mineralogy, and Geophysics, Ruhr University Bochum, 150 Universitätsstrasse, D-44801, Bochum, Germany \\ ${ }^{5}$ Roşia Montana Gold Corporation (RMGC), 321 Piaţa Street, Roşia Montana, Alba County, Romania
}

\begin{abstract}
Alburnite, ideally $\mathrm{Ag}_{8} \mathrm{GeTe}_{2} \mathrm{~S}_{4}$, was discovered in the Cârnicel vein from the Roşia Montana epithermal Au-Ag ore deposit, Apuseni Mountains, Romania. The new mineral is associated with tetrahedrite, galena, pyrite, sphalerite, chalcopyrite, and tellurides (hessite, altaite, and sylvanite). Associated gangue minerals are rhodochrosite, quartz, calcite, and rhodonite. Alburnite was observed only at the microscopic scale as rounded to sub-rounded grains, veinlets or irregular inclusions hosted mainly by tetrahedrite, hessite, and rhodochrosite. Due to the small size of alburnite grains observed so far it was not possible to determine some macroscopic properties; reported properties are based on microscopic observations. The mineral has a metallic luster and is opaque. It is non-fluorescent and has an estimated Mohs hardness of 4 . The mineral shows no cleavage. Density could not be measured because of the small grain size, but calculated density based on the empirical formula is $7.828 \mathrm{~g} / \mathrm{cm}^{3}$. In plane-polarized light in air, alburnite is gray-blue with a bluish tint. It shows no pleochroism or bireflectance in air. Between crossed polars alburnite is isotropic and internal reflections have not been observed in air. The mineral decomposes in intense light. Reflectance minimum values in air (in percents) are: $470 \mathrm{~nm} \mathrm{29.70;546} \mathrm{nm} \mathrm{28.00;} 589 \mathrm{~nm} \mathrm{27.35;650} \mathrm{nm} \mathrm{26.95.} \mathrm{The} \mathrm{average} \mathrm{chemical}$ composition based on 18 electron microprobe analyses from 9 different grains in one polished section is (in wt\%): Ag 65.49, Ge 4.82, Te 20.16, S 9.66, total 100.13. The ideal formula of alburnite, $\mathrm{Ag}_{8} \mathrm{GeTe}_{2} \mathrm{~S}_{4}$, based on 15 apfu requires Ag 65.43, Ge 5.50, Te 19.35, S 9.72, total $100.00 \mathrm{wt} \%$. Features of the crystal structure of alburnite were determined based on electron backscattered diffraction and transmission electron microscopy. Alburnite is cubic, space group F43m, with unit-cell parameters $a$ $=10.4(1) \AA, V=1125(30) \AA^{3}, Z=4$. The strongest eight calculated XRD lines $[d$ in $\AA(I)(h k l)]$ are: 6.004(67)(111), 3.136(48)(113), 3.002(100)(222), 2.600(26)(004), 2.123(33)(224), 2.002(61)(115), $1.838(76)(044)$, and 1.644(12)(026). The name of the new mineral alburnite is derived from the Latin name of the locality. Roşia Montana Au-Ag deposit was known during the Roman period as Alburnus Maior. The mineral and the mineral name have been approved by the Commission on New Minerals, Nomenclature and Classification, IMA 2012-073.
\end{abstract}

Keywords: Alburnite, new mineral, germanium-tellurium sulfosalts, Roșia Montana, Apuseni Mountains, Romania

\section{INTRODUCTION}

The Roşia Montana deposit has a long history of mining that started at least in Roman times. The deposit was known during the Roman period (106-273 AD) as Alburnus Maior (Pošepný 1870; Sîntimbrean 1989) and kilometers of Roman workings are still preserved (Benea and Tămaş 2010; Cauuet and Tămaş 2012). Recent data (Tămaş et al. 2009; Baron et al. 2011) indicate that several $\mathrm{Au}-\mathrm{Ag}$ ore bodies exploited by the Roman miners in Alburnus Maior had Te and Ge traces. The name of the mineral is thus derived from the Latin name of the locality. The first mention of argyrodite from Roşia Montana based on SEM analysis was made by Tămaş (2002), who studied an ore body exploited by the Roman miners in Cârnic massif, Roşia

* E-mail: calingtamas@yahoo.fr
Montana, while the first report of a Te and Ge-bearing mineral indicated by EPMA was made simultaneously by Tămaș et al. (2004), Ciobanu et al. (2004), and Bailly et al. (2005), who interpreted it as Te-bearing argyrodite.

The new mineral was observed so far only at the microscopic scale. The biggest alburnite crystal is close to $50 \mathrm{~mm}$ in size, but usually grains are smaller and range between 10 and $30 \mathrm{~mm}$. The small grain size is the main reason for some limitations of the mineral description (i.e., single-crystal study, macroscopic physical properties, etc.).

The presence of Ge-bearing minerals in Roşia Montana was postulated some time ago. Andronescu (1962) studied the flotation concentrates from Roşia Montana and identified Ge enrichment in pyrite-rich concentrates with low gold grades, but was not able to identify the Ge-bearing mineral. Since the 
first electron microscope evidence of a possibly new Te and Ge-bearing mineral, dating back to Autumn 2000, this mineral was observed in many samples from the Roşia Montana ore deposit, mostly from Ag-rich ore bodies (veins and breccias), some of them mined during Roman times and some of them mined only recently. The above observations indicate that the new mineral, in spite of its small grain size, occurs at the ore deposit scale. LA-ICPMS analyses carried out on sphalerite in alburnite-bearing veins from Roşia Montana (Cook et al. 2009), indicate an average of $73 \mathrm{ppm}$ Ge (as well as $366 \mathrm{ppm}$ Ga and more than $4 \mathrm{wt} \% \mathrm{Mn}$ ) confirming the Ge-rich character of at least some parts of the Roşia Montana deposit.

The mineral and the mineral name have been approved by the Commission on New Minerals, Nomenclature and Classification (CNMNC), IMA 2012-073. The material used for the description of the new mineral was cut in several slices and nine polished sections. Alburnite was observed in six of these polished sections. Co-type material consists of three ore fragments (3230 in two fragments and 3231), and five polished sections (3231B, 3231C, 1064a, 1064b, and 1064c). Reflectance measurements were made on $1064 \mathrm{a}$, but alburnite grains exist on the other sections as well. Microprobe data were gathered from the section 3231C, while crystallographic data (SEM and TEM) were obtained for both $3231 \mathrm{C}$ and 1064a sections. Alburnite grains were recognized optically in all polished sections selected as the cotypes (3231B, $3231 \mathrm{C}, 1064 \mathrm{a}, 1064 \mathrm{~b}$, and 1064c). These sections were made from the three remaining ore fragments (3230 and 3231).

The three ore fragments (two of sample 3230 and one of sample 3231) and four polished sections (3231B, 3231C, 1064a, and $1064 \mathrm{c}$ ) are deposited in the systematic collection of the Mineralogical Museum, Department of Geology, Faculty of Biology and Geology, Babeş-Bolyai University, Cluj-Napoca, Romania. Sample 3231 and the related polished sections are registered under inventory number $71 \mathrm{a} / 1$, and sample 3230 under inventory number $71 \mathrm{a} / 2$. The polished section $1064 \mathrm{~b}$ is hosted by Zentrale Elektronen-Mikrosonde, Institute of Geology, Mineralogy and Geophysics, Ruhr University, Bochum, Germany.

\section{OCCURRENCE}

The new mineral occurs in the Roşia Montana epithermal ore deposit, Apuseni Mountains, Romania (Fig. 1). Roşia Montana represents Europe's largest gold deposit (Manske et al. 2006) with resources exceeding $400 \mathrm{Mt}$ of ore at an average grade of $1.3 \mathrm{~g} / \mathrm{t} \mathrm{Au}$. The deposit is located in the central-eastern part of Apuseni Mountains (Romania), within the so-called Golden Quadrilateral (Ghiţulescu and Socolescu 1941), an area hosting a large number of precious metals ore deposits. An overview of the Neogene tectonic setting, origin of the magmatic/volcanic activity and related porphyry copper and epithermal Au-Ag deposits from the Apuseni Mountains was made by Neubauer et al. (2005) and Roşu et al. (2005).

Roşia Montana is a low to intermediate sulfidation $\mathrm{Au}-\mathrm{Ag}$ deposit (Mârza et al. 1997; Tămaş and Bailly 1998, 1999; Leary et al. 2004; Tămaş et al. 2006) related to $13.65 \pm 0.63$ Ma dacite intrusions (Roşu et al. 2004). The Cretaceous basement (shales, sandstones, and micro-conglomerates) is partly overlain by a vent breccia interbeded with Neogene sedimentary rocks (clays, marls, sandstones, limestones, and gypsum). Lava flows and volcaniclastics of andesitic composition, dated at 9.3 $\pm 0.47 \mathrm{Ma}$ (Roşu et al. 1997) cover the northern and eastern part of Roşia Montana area (Fig. 2). Mineralized and barren phreatomagmatic breccia structures as well as hydrothermal breccias are widespread at ore deposit scale (Tămaş 2010).

Alburnite was discovered in the Cârnicel vein, an intermediate sulfidation structure located in the southern part of Cârnic massif at Roşia Montana. The vein is accessible only underground
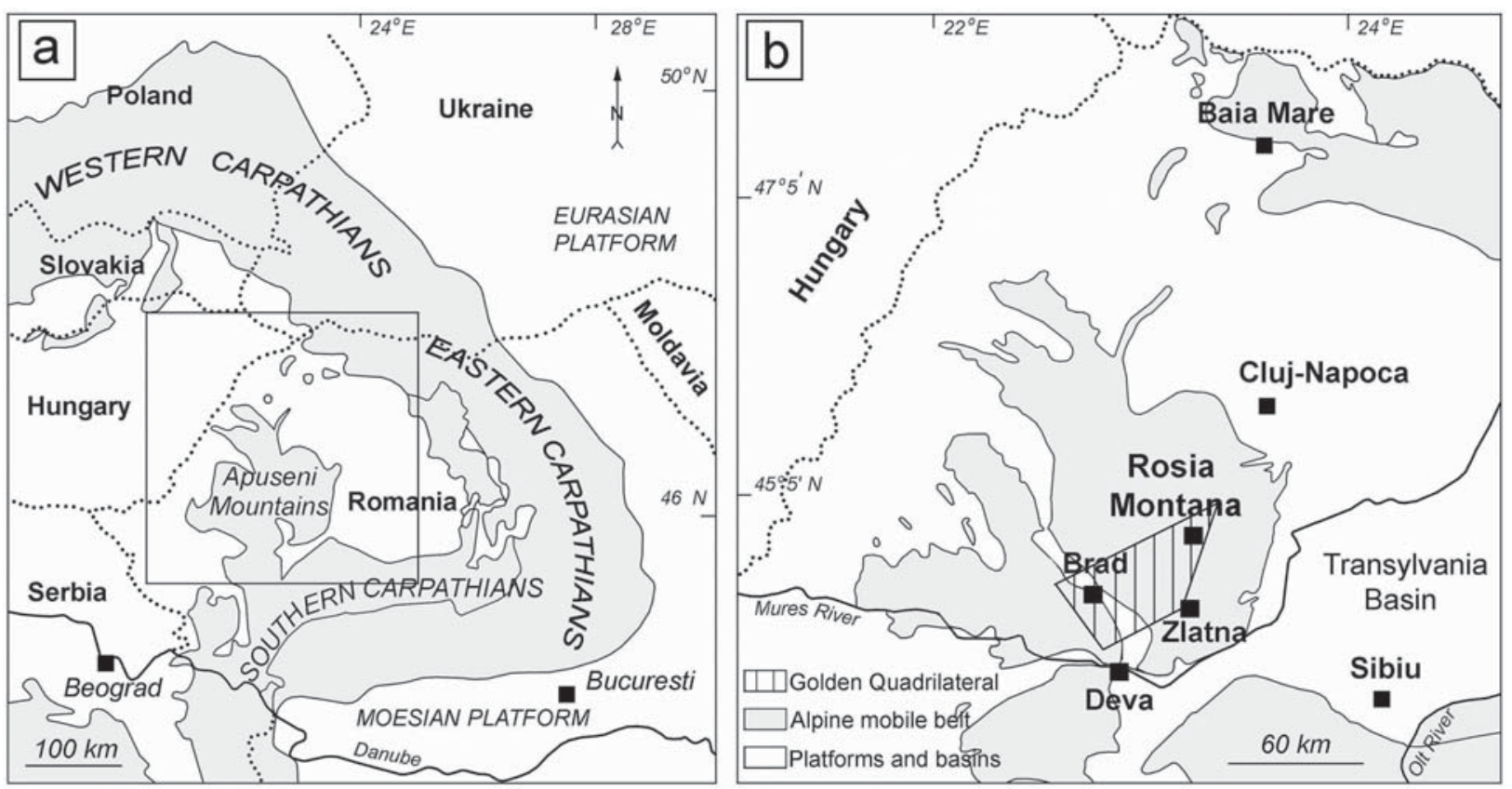

FigURE 1. (a) General map of the Carpathians and the Apuseni Mountains; (b) location of Roşia Montana ore deposit in the Apuseni Mountains. 


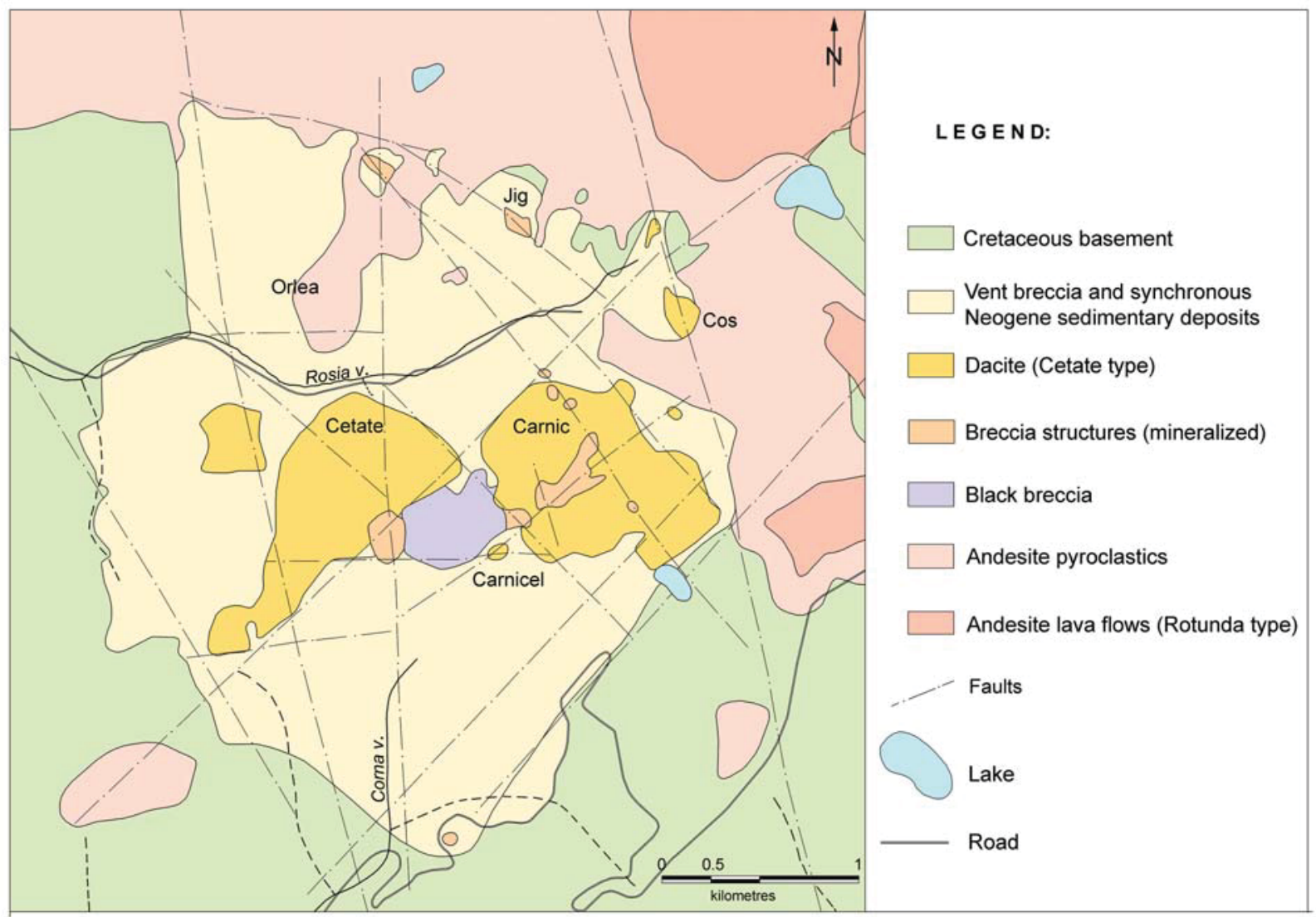

FIGURE 2. Simplified geology of Roşia Montana area (courtesy of Roşia Montana Gold Corporation, with changes).

where it crops out in the so-called Vercheş level or +853 mining level. The Cârnicel vein is hosted in dacitic vent breccias. The vein is oriented almost $\mathrm{N}-\mathrm{S}$ and dips to the west $\left(\sim 70^{\circ}\right)$. The vein is exposed over $170 \mathrm{~m}$ and has an average width of about $25 \mathrm{~cm}$. It has a banded texture with ore-rich layers mixed with carbonate-dominated gangue layers.

The ore mineral assemblage containing the new mineral is dominated by tetrahedrite associated with other sulfides (galena, pyrite, sphalerite, and, rarely, chalcopyrite), and tellurides, mainly hessite but also altaite and sylvanite. Associated gangue minerals are rhodochrosite, quartz, calcite, and rhodonite. Taking into account reflected light microscopic observations, the paragenetic sequence of common sulfides hosting Ag-Te-Ge minerals from Cârnicel vein is shown in Figure 3.

\section{APPEARANCE AND PHYSICAL PROPERTIES}

To date, alburnite has been observed only under the microscope (Fig. 4). It occurs as rounded to sub-rounded grains (Figs. 4a and $4 \mathrm{~b}$ ), veinlets (Figs. 4c, 4d, and 4l) or irregular inclusions (Figs. $4 \mathrm{a}, 4 \mathrm{e}$, and $4 \mathrm{j}$ ) reaching a maximum size of $50 \mu \mathrm{m}$, hosted usually in tetrahedrite, as well as in hessite or located at the contact between these two minerals. It was also observed within galena or between galena and tetrahedrite (Fig. 4a). Large alburnite grains are hosted in late rhodochrosite veinlets that crosscut the tetrahedrite masses (Fig. 4f). Two-phase inclusions, e.g., hessite-alburnite and galena-alburnite, are more frequent than

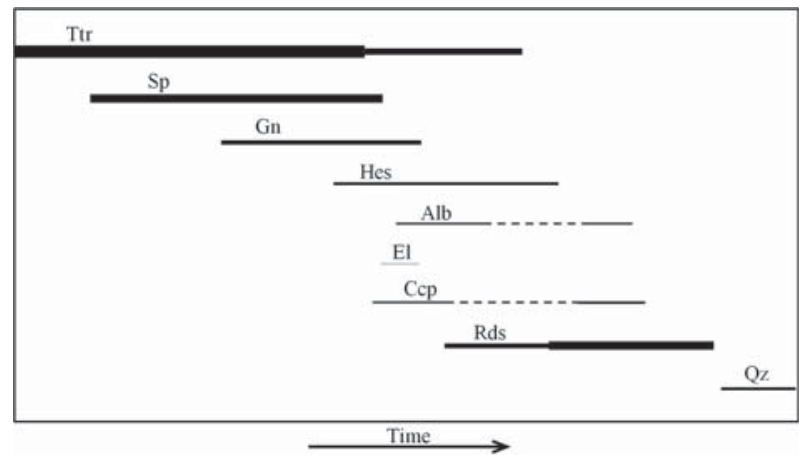

FIGURE 3. Paragenetic sequence of Cârnicel vein, Roşia Montana, showing the main species present in alburnite-bearing mineralization. Abbreviations: Alb = alburnite; $\mathrm{Ccp}=$ chalcopyrite; $\mathrm{El}=$ electrum; $\mathrm{Gn}$ = galena; Hes = hessite; $\mathrm{Qz}=$ quartz; $\mathrm{Sp}=$ sphalerite; $\mathrm{Ttr}=$ tetrahedrite; $\mathrm{Rds}=$ rhodochrosite.

monophasic inclusions with alburnite alone (Fig. 4g). Alburniterhodochrosite assemblages occur within former vugs (Figs. 4i and $4 \mathrm{j}$ ). Alburnite also forms intermingled assemblages with hessite (Fig. 4e), or hessite-rhodochrosite (Fig. 4h). The most complex mineral association with alburnite are assemblages with hessite, chalcopyrite, and galena with or without sphalerite hosted by tetrahedrite (Figs. $4 \mathrm{~b}$ and $4 \mathrm{~h}$ ). Hessite grains with micrometer-size alburnite inclusions may host electrum (Fig. 

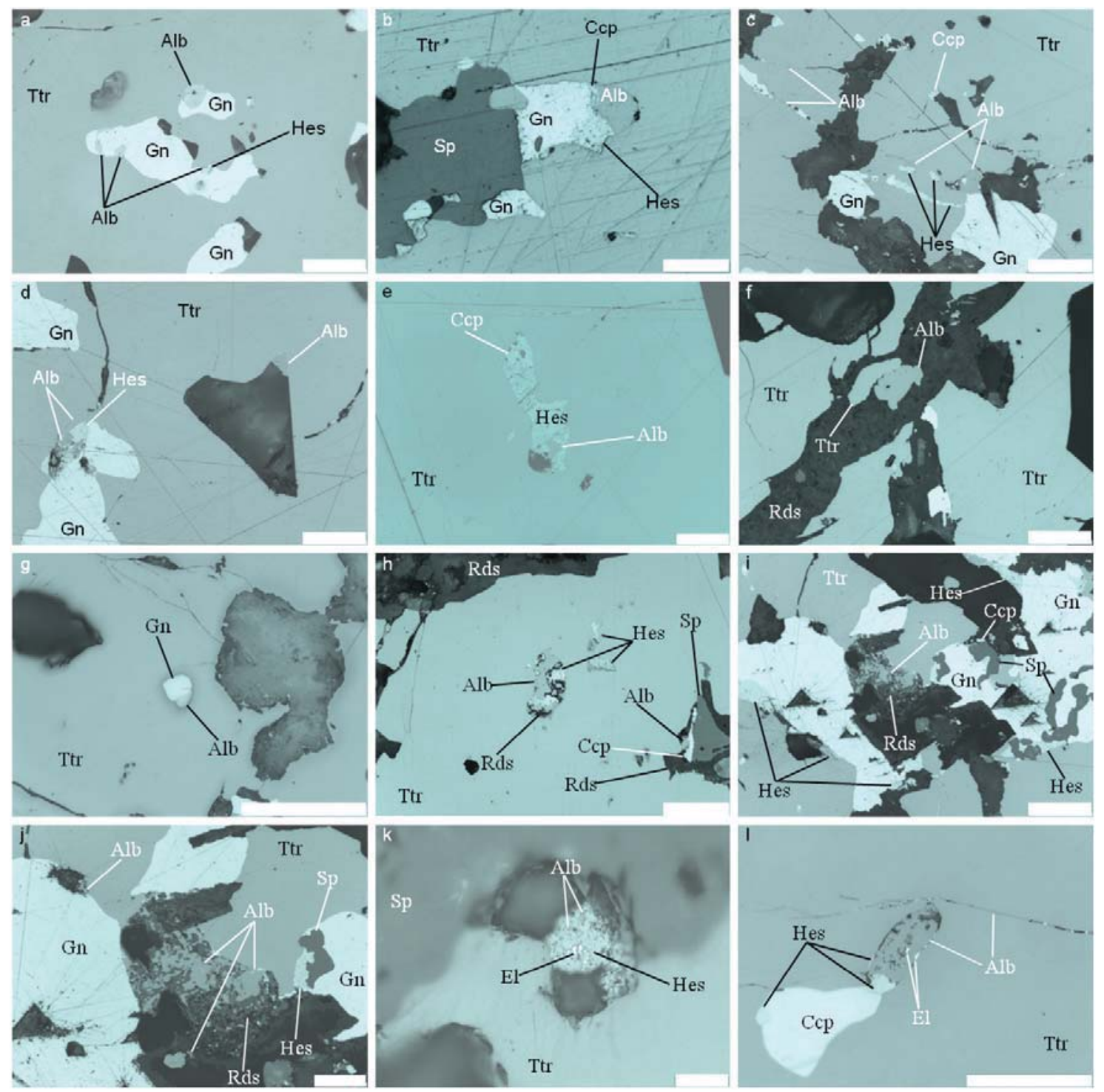

FigURE 4. Optical microscope images (plane-polarized light). (a) Rounded and irregular alburnite inclusions in galena hosted by tetrahedrite and at the contact between galena and tetrahedrite, sometimes associated with hessite (sample 1064C); (b) alburnite-hessite-chalcopyrite-galena inclusion related to sphalerite hosted in tetrahedrite (sample 3231C); (c) irregular alburnite grains and veinlets with hessite, galena, and chalcopyrite within tetrahedrite (sample 1064B); (d) alburnite-hessite and chalcopyrite deposited in vugs (presently filled with rhodochrosite) and as veins in tetrahedrite (sample 1064A); (e) irregular inclusion of alburnite in hessite associated with chalcopyrite hosted in tetrahedrite (sample 1064B); (f) alburnite attached to tetrahedrite in a rhodochrosite vein crosscutting tetrahedrite (sample 1064A); (g) galena-alburnite inclusion in tetrahedrite (sample 3231C); (h) mixed alburnite-hessite-rhodochrosite inclusions in tetrahedrite, and alburnite-chalcopyrite-sphalerite in a void filled with rhodochrosite in tetrahedrite; inclusions of hessite-alburnite \pm chalcopyrite within tetrahedrite (sample 3231E); (i) alburnite-rhodochrosite associated with galena, hessite, sphalerite, and chalcopyrite in tetrahedrite (sample 1064B); (j) detail of i ; (k) hessite-alburnite inclusion with associated electrum in a vug at the contact of tetrahedrite-sphalerite (sample 3231C); (l) an alburnite bleb hosting electrum; alburnite is associated with hessite and chalcopyrite and occurs in the same mineral association also as veinlets in tetrahedrite; the gray spots on alburnite formed within a few minutes in intense light (sample 1064A). Abbreviations: Alb = alburnite; $\mathrm{Ccp}=$ chalcopyrite; $\mathrm{El}=$ electrum; $\mathrm{Gn}=$ galena; Hes = hessite; $\mathrm{Sp}=\mathrm{sphalerite;} \mathrm{Ttr}$

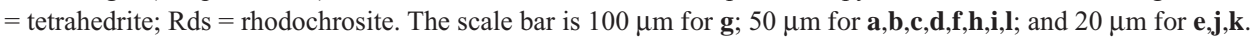

$4 \mathrm{k})$. Electrum was also observed as inclusions in alburnite and along the contact of alburnite with its tetrahedrite host (Fig. 41).

Due to the small size of alburnite grains observed so far $(<50$ $\mu \mathrm{m})$ it was not possible to determine the macroscopic properties of the new mineral. However, some properties are reported based on microscopic observations. The mineral has a metallic luster and it is opaque. It is non-fluorescent and has an estimated Mohs hardness of 4 . The mineral shows no cleavage. Density could not be measured because of the small grain size, but calculated density based on the empirical formula is $7.828 \mathrm{~g} / \mathrm{cm}^{3}$. 
TABLE 1. Reflectance data for alburnite compared with putzite (Paar et al. 2004), argyrodite (Criddle and Stanley 1993), and canfieldite (Criddle and Stanley 1986)

\begin{tabular}{lcccc}
\hline$\lambda(\mathrm{nm})$ & $R(\%)$ Alburnite & $R(\%)$ Putzite & $R(\%)$ Argyrodite & $R$ (\%) Canfieldite \\
\hline 400 & 32.00 & 33.50 & 29.30 & 28.50 \\
420 & 31.20 & 31.60 & 27.60 & 27.75 \\
440 & 30.60 & 30.60 & 26.60 & 27.00 \\
460 & 30.00 & 29.40 & 25.90 & 26.30 \\
470 & 29.70 & 28.90 & 25.60 & 25.90 \\
480 & 29.30 & 28.60 & 25.20 & 25.70 \\
500 & 29.00 & 27.80 & 24.80 & 25.20 \\
520 & 28.50 & 27.20 & 24.50 & 24.90 \\
540 & 28.10 & 26.70 & 24.30 & 24.70 \\
546 & 28.00 & 26.50 & 24.20 & 24.60 \\
560 & 27.75 & 26.30 & 24.20 & 24.50 \\
580 & 27.50 & 26.00 & 24.20 & 24.50 \\
589 & 27.35 & 25.80 & 24.10 & 24.50 \\
600 & 27.20 & 25.70 & 24.00 & 24.40 \\
620 & 27.10 & 25.40 & 24.00 & 24.40 \\
640 & 27.00 & 25.30 & 23.90 & 24.50 \\
650 & 26.95 & 25.30 & 24.00 & 24.60 \\
660 & 26.90 & 25.20 & 24.00 & 24.60 \\
680 & 26.85 & 25.20 & 24.00 & 24.70 \\
700 & 26.80 & 25.20 & 24.10 & 24.90 \\
\hline
\end{tabular}

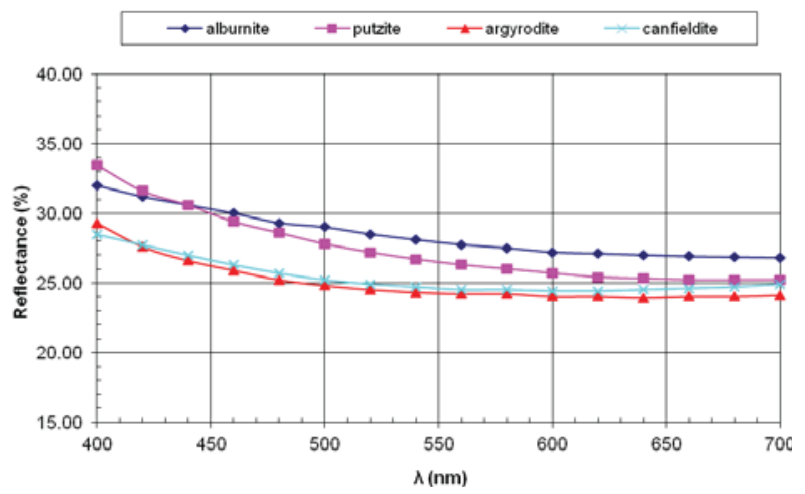

FIGURE 5. Reflectance spectra in air for alburnite, putzite (Paar et al. 2004), argyrodite (Criddle and Stanley 1993), and canfieldite (Criddle and Stanley 1986).

\section{OPTICAL PROPERTIES}

In polished sections illuminated by plane-polarized light, alburnite is gray with a bluish tint (Fig. 4), having lower reflectance than tetrahedrite, the main host mineral. Te-bearing canfieldite, $\mathrm{Ag}_{8} \mathrm{Sn}(\mathrm{S}, \mathrm{Te})_{6}$, first mentioned by Harris and Owens (1971), has the same bluish tint in plane-polarized light in air (Soeda et al. 1984; Wimmers 1985). By comparison, Te-free argyrodite and canfieldite have a pinkish brown to violet tint in reflected light (Uytenbogaardt and Burke 1971). Alburnite shows neither pleochroism nor bireflectance (in air). Between crossed polars alburnite is isotropic. Internal reflections have not been observed in air. The mineral decomposes in intense light (Fig. 41).

Reflectance measurements were carried out in air using a Hamamatsu C100838CA spectrometer attached to a Leitz Orthoplan microscope. The device was calibrated with a Zeiss $\mathrm{SiC}$ reflectance standard (No. 787). A $20 \times$ objective with an effective numerical aperture of 0.2 was used. The diameter of the measured area was about $10 \mu \mathrm{m}$. The original spectrum was recorded at 712 different wavelengths. Reflectance minimum values and a selection of 16 values between 400 and $700 \mathrm{~nm}$ in steps of $20 \mathrm{~nm}$ together with those for argyrodite, canfieldite,
TABLE 2. Analytical data (wt\%) for alburnite, Cârnicel vein, Roşia Montana, Romania

\begin{tabular}{lccccc}
\hline No. & $\mathrm{Ag}$ & $\mathrm{Ge}$ & $\mathrm{Te}$ & $\mathrm{S}$ & Total \\
\hline 1 & 65.32 & 4.91 & 20.68 & 9.35 & 100.26 \\
2 & 65.65 & 5.06 & 19.80 & 9.68 & 100.19 \\
3 & 65.36 & 5.09 & 20.22 & 9.59 & 100.26 \\
4 & 66.03 & 5.02 & 20.03 & 9.57 & 100.65 \\
5 & 64.74 & 4.74 & 19.75 & 9.51 & 98.74 \\
6 & 65.05 & 4.77 & 19.99 & 9.53 & 99.34 \\
7 & 65.48 & 4.65 & 20.69 & 9.58 & 100.40 \\
8 & 65.35 & 4.97 & 19.99 & 9.75 & 100.06 \\
9 & 66.02 & 4.86 & 20.20 & 9.68 & 100.76 \\
10 & 65.64 & 4.80 & 20.32 & 9.70 & 100.46 \\
11 & 65.48 & 4.82 & 19.73 & 9.81 & 99.84 \\
12 & 65.20 & 4.83 & 19.38 & 9.95 & 99.36 \\
13 & 65.14 & 4.70 & 20.17 & 9.73 & 99.74 \\
14 & 65.92 & 4.81 & 20.27 & 9.74 & 100.74 \\
15 & 65.73 & 5.00 & 19.96 & 9.65 & 100.34 \\
16 & 65.79 & 4.64 & 20.72 & 9.68 & 100.83 \\
17 & 66.49 & 4.13 & 20.53 & 9.43 & 100.58 \\
18 & 64.40 & 4.87 & 20.38 & 9.96 & 99.61 \\
average & 65.49 & 4.82 & 20.16 & 9.66 & 100.13 \\
\hline
\end{tabular}

and putzite (Criddle and Stanley 1986, 1993; Paar et al. 2004) are given in Table 1.

The new mineral shows systematically greater reflectance than argyrodite and canfieldite $(\sim 3 \%)$. As compared with putzite, alburnite has a lower reflectance between 400 and $440 \mathrm{~nm}$ and is more reflective at wavelengths greater than $440 \mathrm{~nm}$ (Fig. 5).

\section{CHEMical DATA}

Chemical analyses (18 from 9 different grains in one polished section) were carried out using a JEOL JXA-8200 electron microprobe (WDS mode, $15 \mathrm{kV}, 20 \mathrm{nA},<1 \mu \mathrm{m}$ beam diameter, and a counting time of $30 \mathrm{~s}$ ). Preliminary EDS analysis revealed the presence of only four elements, $\mathrm{Ag}, \mathrm{Ge}, \mathrm{Te}$, and $\mathrm{S}$. Naumannite $\left(\mathrm{Ag}_{2} \mathrm{Se}\right)$, pyrite $\left(\mathrm{FeS}_{2}\right)$, cassiterite $\left(\mathrm{SnO}_{2}\right)$, Ge metal, and Te metal were used as standards. Sn contents in all analyses were below detection limits $(0.03 \mathrm{wt} \% \mathrm{Sn})$. We used the following lines for the analysis: $\mathrm{S} K \alpha, \operatorname{Ag} L \alpha, \mathrm{Ge} L \alpha, \operatorname{Sn} L \alpha$, and $\mathrm{Te} L \alpha$. Detection limits (wt\%) were 0.09 for $\mathrm{Ag}, 0.03$ for $\mathrm{Ge}, 0.05$ for $\mathrm{S}, 0.03$ for $\mathrm{Sn}$, and 0.03 for Te. Analytical data are given in Table 2 .

The empirical formula of alburnite based on 15 apfu is $\mathrm{Ag}_{8.04} \mathrm{Ge}_{0.88} \mathrm{Te}_{2.09} \mathrm{~S}_{3.99}$. The simplified formula is $\mathrm{Ag}_{8} \mathrm{GeTe}_{2} \mathrm{~S}_{4}$, which requires $\mathrm{Ag} 65.43$, Ge 5.50, Te 19.35, S 9.72, total $100.00 \mathrm{wt} \%$.

\section{CRystallography}

The new mineral occurs only as microscopic grains up to $50 \mu \mathrm{m}$ in size. All diffraction data were obtained by electron backscatter diffraction (EBSD) and electron diffraction (ED).

Argyrodite-type $\mathrm{M}_{8} \mathrm{XC}_{6}$ structures $(\mathrm{M}=\mathrm{Ag}, \mathrm{Cu} ; \mathrm{X}=\mathrm{Si}, \mathrm{Ge}$, $\mathrm{Sn}$, etc.; $\mathrm{C}=\mathrm{S}, \mathrm{Te}, \mathrm{Se}$ ) have a common cubic high-temperature $\gamma$ phase, space group $F \overline{4} 3 m$. At lower temperatures, several ordered structures exist, such as the $\beta^{\prime \prime}$ structure with orthorhombic symmetry in which argyrodite crystallizes at room temperature. The phase with the lowest transformation temperature to the cubic structure is the synthetic compound $\mathrm{Ag}_{8} \mathrm{GeTe}_{6}\left(-29{ }^{\circ} \mathrm{C}\right.$, $\beta \rightarrow \gamma$ ), whereas the cubic modification of argyrodite sensu stricto is only stable above $234{ }^{\circ} \mathrm{C}$ (Gorochov 1968; Katty et al. 1981). Tellurium on the $\mathrm{C}$ site seems to extend the stability field of the $\gamma$ phase to lower temperatures. Putzite has the cubic $\gamma$ structure at room temperature. The close synthetic analog of 
putzite, $\mathrm{Cu}_{8} \mathrm{GeS}_{6}$, has also a low transformation temperature (55 $\left.{ }^{\circ} \mathrm{C}, \beta^{\prime} \rightarrow \gamma\right)$. Diffraction data for the new mineral can only be indexed as a cubic phase, which makes the $\gamma$ phase structure a likely candidate.

The $\gamma$-phase structure $(Z=4)$ has three partially filled metal positions ( $M$; Wyckoff positions $\left.24 g, 48 h^{1}, 48 h^{2}\right)$, one germanium position ( $4 b$ ), and 3 positions for the chalcogenides, two of them completely filled $\left(4 d, 16 e^{1}\right)$ and one with an occupancy of $0.25\left(16 e^{2}\right)$. The $16 e^{1}$ position contains thus $2 / 3$ of the total chalcogenides in the formula unit and the two other sites ( $4 d$ and $16 e^{2}$ ) are occupied by the remaining $1 / 3$. The ratio of 0.5 between tellurium and sulfur in the new mineral may reflect the distribution of the chalcogenides among the three sites, i.e., tellurium occupying the $16 e^{2}$ and $4 d$ sites and sulfur the $16 e^{1}$ site.

\section{Electron backscattered diffraction}

Two ore samples were diamond polished and then chemically mechanically lapped with a colloidal silica suspension $(20 \mathrm{~nm})$ to remove polishing damage. EBSD measurements, carried out on polished sections $3231 \mathrm{C}$ and $1064 \mathrm{a}$, were performed using a FEI XL30 Sirion FEG SEM equipped with an EDAX-EBSD OIM system and a DigiView detector, and using Delphi software for data interpretation. The samples were tilted $70^{\circ}$ from the horizontal SEM stage plane. The indexing quality is given by the confidence index $(\mathrm{CI})$, which allows to discriminate between different solutions (values ranging between 0 and 1 , solutions $\mathrm{CI}$ $>0.2$ are considered to be reliable, Mauler et al. 2000), and the fit factor, which describes the angular deviation between calculated and measured Kikuchi lines (good fit for deviations $<1.0^{\circ}$ ).

Patterns of tetrahedrite present in the matrix were collected to calibrate the EBSD system. Calibration settings were verified for sphalerite, galena, and rhodochrosite. Afterward, 25 patterns from 7 different alburnite grains were collected (Fig. 6). The low-temperature orthorhombic structure of argyrodite gave no match at all between calculated and measured patterns. Matching patterns were obtained for all 25 patterns using the $\gamma$ phase structure.

\section{Transmission electron microscopy}

Tetrahedrite grains, the main host of the new phase, were crushed in a mortar and the resulting powder deposited onto carbon-coated copper grids. The samples were analyzed with a Philips CM200 transmission electron microscope operated at 200 $\mathrm{kV}$, calibrated using a gold standard. Two grains of the new phase were found and analyzed by selected-area electron diffraction. The diffractograms were indexed for a cubic phase with a lattice parameter of 10.4 \pm 0.1 Å using JEMS software (Stadelmann 1987).

Due to the large thickness of the grains, we were only able to obtain good (001) SAED patterns (Fig. 7). They can be indexed based on a cubic cell and are compatible with an F-centered lattice. Simulation (JEMS software; Stadelmann 1987) of the (001) diffraction pattern using the $\gamma$ phase structure with the chalcogenide distribution indicated above reproduced for several thicknesses the characteristic square pattern with weak (220) reflections. Other chalcogenide distribution were tested i.e., sulfur on $16 e^{2}$ or on $4 d$ and one of the $16 e$ sites. None of these distributions gave the characteristic weak intensity observed for the $2 h 2 k 0$ reflections.

Powder XRD data could not be collected, but a calculated data set is given in Table 3. The powder pattern was calculated with the software "Crystaldiffract V5.2" (Crystalmaker Software) for the $\gamma$-phase structure taking the atomic coordinates given by Paar et al. (2004) for putzite, the $a$-lattice parameter determined from the SAED pattern $(10.4 \AA)$ with the chalcogenides distributed onto the following sites: Te on $4 d$ (full occupation) and $16 e^{2}$ (occupation: 0.25 ) and sulfur on $16 e^{1}$ (full occupation). The peak positions were determined for monochromatic $\mathrm{CuK \alpha} \alpha_{1}$ radiation. Peak intensities were determined using scattering factors given by Doyle and Turner (1968) and taking into account Lorentz polarization and reflection multiplicity.

\section{RELATION TO OTHER SPECIES}

Alburnite is considered to be part of the argyrodite-canfieldite series. The stoichiometry of the new mineral is the same as for the minerals of the argyrodite group (Strunz classification 02.BA.35), which contains three members, one with orthorhombic symmetry, argyrodite $\mathrm{Ag}_{8} \mathrm{GeS}_{6}$, one with cubic symmetry, putzite, $\left(\mathrm{Cu}_{4.7} \mathrm{Ag}_{3.3}\right)_{\Sigma 8} \mathrm{GeS}_{6}$ (Paar et al. 2004), and one whose structure has not been determined but is usually given as orthorhombic, canfieldite, $\mathrm{Ag}_{8} \mathrm{SnS}_{6}$. Recently a further Ge-bearing sulfosalt related to the argyrodite group has been described
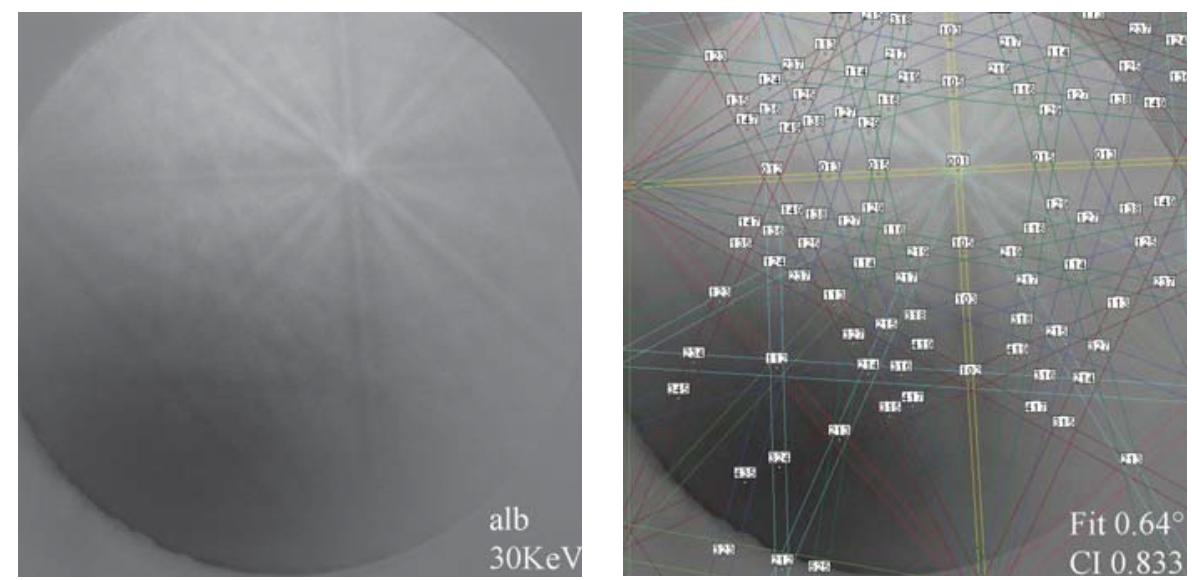

FIGURE 6. Example of EBSD pattern indexation of the 25 patterns indexed using the $\gamma$-phase structure. The confidence indices and the fit factors are indicated. 
TABLE 3. Calculated powder XRD data for alburnite

\begin{tabular}{llllc}
\hline$h$ & $k$ & $l$ & $d$ & $I_{\text {rel }}$ \\
\hline $\mathbf{1}$ & $\mathbf{1}$ & $\mathbf{1}$ & $\mathbf{6 . 0 0 4}$ & $\mathbf{6 7}$ \\
0 & 0 & 2 & 5.200 & 3 \\
0 & 2 & 2 & 3.677 & 11 \\
$\mathbf{1}$ & $\mathbf{1}$ & $\mathbf{3}$ & $\mathbf{3 . 1 3 6}$ & $\mathbf{4 8}$ \\
$\mathbf{2}$ & $\mathbf{2}$ & $\mathbf{2}$ & $\mathbf{3 . 0 0 2}$ & $\mathbf{1 0 0}$ \\
$\mathbf{0}$ & $\mathbf{0}$ & $\mathbf{4}$ & $\mathbf{2 . 6 0 0}$ & $\mathbf{2 6}$ \\
1 & 3 & 3 & 2.386 & 2 \\
0 & 2 & 4 & 2.326 & 11 \\
$\mathbf{2}$ & $\mathbf{2}$ & $\mathbf{4}$ & $\mathbf{2 . 1 2 3}$ & $\mathbf{3 3}$ \\
$\mathbf{1}$ & $\mathbf{1}$ & $\mathbf{5}$ & $\mathbf{2 . 0 0 2}$ & $\mathbf{6 1}$ \\
$\mathbf{0}$ & $\mathbf{4}$ & $\mathbf{4}$ & $\mathbf{1 . 8 3 8}$ & $\mathbf{7 6}$ \\
1 & 3 & 5 & 1.758 & 9 \\
0 & 0 & 6 & 1.733 & 3 \\
0 & 2 & 6 & 1.644 & 12 \\
3 & 3 & 5 & 1.586 & 8 \\
2 & 2 & 6 & 1.568 & 8 \\
4 & 4 & 4 & 1.501 & 12 \\
1 & 1 & 7 & 1.456 & 6 \\
0 & 4 & 6 & 1.442 & 1 \\
2 & 4 & 6 & 1.390 & 1 \\
1 & 3 & 7 & 1.354 & 6 \\
0 & 0 & 8 & 1.300 & 6 \\
3 & 3 & 7 & 1.271 & 3 \\
0 & 2 & 8 & 1.261 & 3 \\
0 & 6 & 6 & 1.226 & 7 \\
1 & 5 & 7 & 1.201 & 6 \\
2 & 6 & 6 & 1.193 & 12 \\
0 & 4 & 8 & 1.163 & 9 \\
1 & 1 & 9 & 1.142 & 7 \\
2 & 4 & 8 & 1.135 & 1 \\
4 & 6 & 6 & 1.109 & 5 \\
\hline Note: & Bold numbers are seven strongest lines. & \\
\hline & & & \\
\hline
\end{tabular}
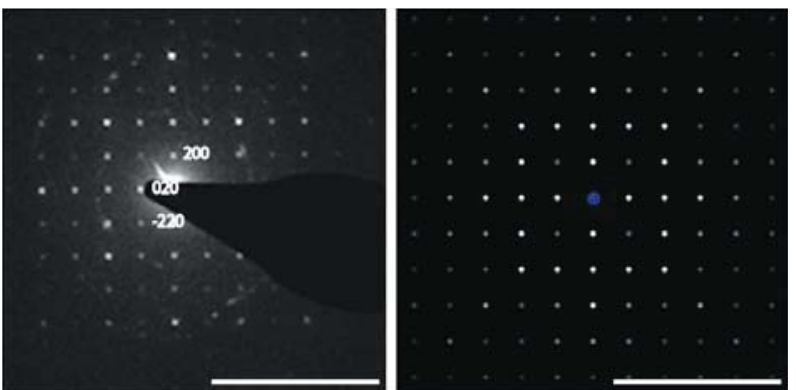

FIGURE 7. Experimental (001) SAED pattern (left) and simulated (001) diffraction pattern (right); thickness of slice $125 \mathrm{~nm}$. The simulated diffraction pattern was obtained using the calibrations, LZ 0 , center of Laue circle (000), zone axis: [001], tilt angle $0.00^{\circ}$, acceleration voltage $200 \mathrm{kV}$, camera length $1395 \mathrm{~mm}$. The scale bar is $20 \mathrm{~nm}$ for each image.

from Argentina, catamarcaite $\mathrm{Cu}_{6} \mathrm{GeWS}_{8}$ (Putz et al. 2006). The chemical composition of the new mineral is closest to argyrodite, which has two of the six sulfur atoms replaced by tellurium, though with cubic symmetry.

Tellurium as minor element was already reported for different species of the argyrodite-canfieldite group. Te-bearing canfieldite was first reported by Harris and Owens (1971) from Revelstoke, Canada, with the following composition (wt\%): Ag 65.12(100), Sn 10.57(50), Ge-, Te 8.69(50), S 13.95(100), total 98.33. Wimmers (1985) reported Te-bearing canfieldite from Panasqueira, Portugal, with the following average composition (wt\%): Ag 57.39, Sn 9.8, Te 19.095, S 9.86, Cu 2.44, Fe 1.95, Zn 0.08, total 100.62 .

A Te-bearing silver-germanium sulfosalt found in association with hessite, Ag-Au tellurides, altaite, and base metal sulfides
TABLE 4. XRD data for synthetic $\gamma-\mathrm{Ag}_{8} \mathrm{GeTe}_{6}$ at room temperature (Boucher et al. 1993)

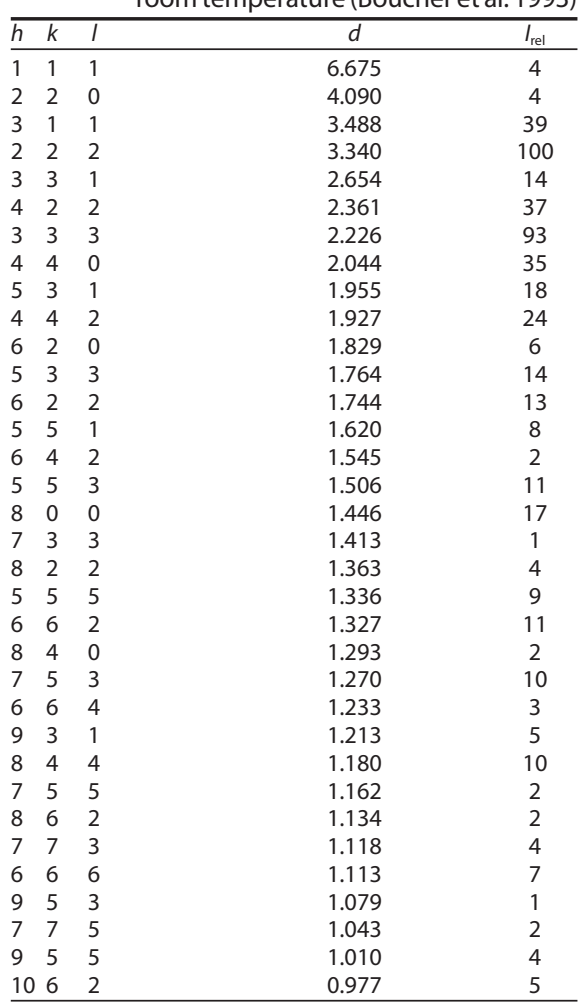

(tetrahedrite, galena, sphalerite, chalcopyrite, etc.) was first mentioned by Tămaş et al. (2004) from Roşia Montana, based on EPMA data, but no crystallographic data were determined. Based on the sole chemical data, Ciobanu et al. (2004), Bailly et al. (2005), and Tămaş et al. (2006) interpreted this mineral as a Te-bearing argyrodite. Tămaş et al. (2006) suggested the existence of a possible solid solution between $\mathrm{Ag}_{8} \mathrm{GeS}_{6}$ and $\mathrm{Ag}_{8} \mathrm{GeTe}_{6}$, which is known only as a synthetic phase (Boucher et al. 1993). The XRD data obtained by Boucher et al. (1993) for synthetic $\gamma-\mathrm{Ag}_{8} \mathrm{GeTe}_{6}$ (space group $F \overline{4} 3 m, a=11.5656 \AA$, $Z$ $=4$ ) are given in Table 4 for comparison.

$\mathrm{Gu}$ et al. (2012) reported a new member of the argyroditecanfieldite series with orthorhombic symmetry, tellurocanfieldite $\mathrm{Ag}_{8} \mathrm{SnTe}_{2} \mathrm{~S}_{4}$, from Bajiazi Pb-Zn ore deposit, Jianchang County, Liaoning Province, China. Although initially approved by IMA Commission on New Minerals, Nomenclature and Classification as the new mineral IMA 2012-013, this approval was subsequently withdrawn (Williams et al. 2012) following a single-crystal study on Te-rich canfieldite from Lengenbach quarry, Binntal, Switzerland (Bindi et al. 2012). This study indicated that this phase is cubic and not orthorhombic and that the distribution of substituted Te atoms is disordered over the three sulfur sites. The problem is that the structure of pure canfieldite has not been determined so far. It is usually given as orthorhombic. If this should turn out to be true, the structural relationship between the rejected "tellurocanfieldite" and canfieldite may be similar to the relationship between alburnite and argyrodite, where tellurium substituting for sulfur stabilizes the cubic structure to lower temperatures. 


\section{ACKNOWLEDGMENTS}

Thanks are due to Roşia Montana Gold Corporation, Romania, for field support and access to geological data. Many thanks to Cristoph Neururer, University of Fribourg, Switzerland, for EBSD pattern acquisition and interpretation. Eric Reusser, ETH Zurich, Switzerland, supported us with the electron probe microanalyses. We acknowledge the highly valuable comments of P. Williams and the CNMNC members. American Mineralogist reviewers Florencia Márquez-Zavalía and Nigel J. Cook, and Associate Editor Fernando Colombo provided helpful comments and suggestions.

\section{REFERENCES CITED}

Andronescu, A. (1962) The distribution of germanium in various ores from R.P.R Revista Minelor, XIII, 11, 498-501 (in Romanian).

Bailly, L., Tămaş, C.G., and Minuţ, A. (2005) Te-rich argyrodite occurrence in Rosia Montana ore deposit, Apuseni Mountains, Romania. Comptes Rendus Geoscience, 337, 755-762.

Baron, S., Tămaş, C.G., Cauuet, B., and Munoz, M. (2011) Lead isotopes analyses of gold-silver ores from Roșia Montana (Romania): A first step of metal provenance study of Roman mining activity in Alburnus Maior (Roman Dacia). Journal of Archaeological Sciences, 38, 1090-1100.

Benea, M., and Tămaş, C.G. (2010) Neogene volcanics in the Apuseni Mts.: historical mining, and gold deposits. IMA Field trip Guide RO3, Acta MineralogicaPetrographica, University of Szeged, Hungary, 21, 24p.

Bindi, L., Nestola, F., Guastoni, A., Zorzi, F., Peruzzo, L., and Raber, T. (2012) Te-rich canfieldite, $\mathrm{Ag}_{8} \mathrm{Sn}(\mathrm{S}, \mathrm{Te})_{6}$, from the Lengenbach quarry, Binntal, Canton Valais, Switzerland: occurrence, description and crystal structure. Canadian Mineralogist, 50, 111-118

Boucher, F., Evain, M., and Brec, R. (1993) Distribution and ionic diffusion path of silver in $\gamma-\mathrm{Ag}_{8} \mathrm{GeTe}_{6}$ : A temperature dependent anharmonic single crystal structure study. Journal of Solid State Chemistry, 107, 332-346.

Cauuet, B., and Tămaş, C.G. (2012) Antique mining works from Roşia Montana (Romania). Intermingled data between archaeology and geology. In A. Orejas and C. Rico, Eds., Antique Mining and Metallurgy. Visions and revisions. Tribute to Claude Domergue, p. 219-241. Collection de la Casa de Velázquez, 128, Madrid (in French)

Ciobanu, C.L., Cook, N.J, Tămaş, C., Leary, S., Manske, S., O'Connor, G., and Minut, A. (2004) Telluride-gold-base metal associations at Roșia Montana: the role of hessite as gold carrier. In N.J. Cook and C.L. Ciobanu, Eds., Goldsilver-telluride deposits of the Golden Quadrilateral, South Apuseni Mts., Romania: Guidebook of the International Field Workshop of IGCP project 486, p. 187-202. The International Association on the Genesis of Ore Deposits (IAGOD) Guidebook Series, 12

Cook, N.J., Ciobanu, C.L., Pring, A., Skinner, W., Shimizu, M., Danyushevsky, L.V., Saini-Eidukat, B., and Melcher, F. (2009) Trace and minor elements in sphalerite: A LA-ICPMS study. Geochimica et Cosmochimica Acta, 73, 4761-4791

Criddle, A.J., and Stanley, C.J. (1986) The quantitative data file for ore minerals of the commission on ore microscopy of the International Mineralogical Association, 420 p. Alden Press, Oxford, British Museum (Natural History).

(1993) The quantitative data file for ore minerals. The Commission on Ore Mineralogy, International Mineralogical Association, 635 p. Chapman and Hall, London, U.K

Doyle, P.A., and Turner, P.S. (1968) Relativistic hartree-fock X-ray and electron scattering factors. Acta Crystallographica, A24, 390-397.

Ghiţulescu, T.P., and Socolescu, M. (1941) Geological and mining study of Metaliferi Mountains (Golden Quadrilateral and surrounding areas). Annuaire de l'Institut Géologique Roumain, XXI, 181-463 (in French).

Gorochov, O. (1968) Compounds $\mathrm{Ag}_{8} \mathrm{MX}_{6}(\mathrm{M}=\mathrm{Si}, \mathrm{Ge}, \mathrm{Sn}$ and $\mathrm{X}=\mathrm{S}, \mathrm{Se}, \mathrm{Te})$. Bulletin de la Société Chimique de France, 6, 2263-2270.

Gu, X., Xie, X., Lu, A., Hoshino, H., Huang, J., and Li, J. (2012) Tellurocanfieldite, IMA 2012-013. CNMNC Newsletter 13, June 2012, 816. Mineralogical Magazine, 76, 807-817.

Harris, D.C., and Owens, D.R. (1971) A tellurium-bearing canfieldite, from Revelstoke, B.C. Canadian Mineralogist, 10, 895-898.

Katty, A., Gorochov, O., and Letoffe, J.M. (1981) Radiocrystallographic and calorimetric study of the phase-transitions of $\mathrm{Ag}_{8} \mathrm{GeTe}_{6}$. Journal of Solid State Chemistry, 38, 259-263.

Leary, S., O'Connor, G., Minuț, A., Tămaş, C.G., Manske, S., and Howie, K. (2004) The Roșia Montana deposit. In N.J Cook and C.L. Ciobanu, Eds., Gold-SilverTelluride Deposits of the Golden Quadrilateral, South Apuseni Mts., Romania: guidebook of the International Field Workshop of IGCP project 486, Alba Iulia, Romania, vol. 12, p. 89-98. IAGOD Guidebook Series.

Manske, S.L., Hedenquist, J.W., O'Connor, G., Tămaş, C.G., Cauuet, B., Leary, S., and Minuț, A. (2006) Roşia Montana, Romania: Europe's largest gold deposit. Society of Economic Geologists Newsletter, 64, 9-15.

Mârza, I., Tămas, C.G., and Ghergari, L. (1997) Low sulfidation epithermal gold deposits from Roșia Montana, Metaliferi Mountains, Romania. Studii și Cercetări de Geologie, 42, 3-12.
Mauler, A., Bystricky, M., Kunze, K., and Mackwell, S.J. (2000) Microstructures and lattice preferred orientations in experimentally deformed clinopyroxene aggregates. Journal of Structural Geology, 22, 1633-1648.

Neubauer, F., Lips, A., Kouzmanov, K., Lexa, J., and Ivășcanu, P. (2005) Subduction, slab detachment and mineralization: the Neogene in the Apuseni Mountains and Carpathians. Ore Geology Reviews, 27, 13-44.

Paar, W.H., Roberts, A.C., Berlepsch, P., Armbruster, T., Topa, D., and Zagler, G. (2004) Putzite, $\left(\mathrm{Cu}_{4.7} \mathrm{Ag}_{3.3}\right)_{\Sigma 8} \mathrm{GeS}_{6}$, a new mineral from Capillitas, Catamarca, Argentina: description and crystal structure. Canadian Mineralogist, 42, $1757-1769$.

Pošepný, F. (1870) Geological and mining archaeological description of the map of Roșia Montana gold mining district, Transylvania. Verhandlungen der Kaiserlich-Königlichen Geologischen Reichsanstalt, 2, 19-20 (in German).

Putz, H., Paar, W.H., Topa, D., Makovicky, E., and Roberts, A.C. (2006) Catamarcaite, $\mathrm{Cu}_{6} \mathrm{GeWS}_{8}$, a new germanium sulfide mineral species from Capillitas, Catamarca, Argentina: description, paragenesis and crystal structure. Canadian Mineralogist, 44, 1481-1497.

Roșu, E., Pécskay, Z., Stefan, A., Popescu, G, Panaiotu, C., and Panaiotu, C.E. (1997) The evolution of the Neogene volcanism in the Apuseni Mountains (Romania): constraints from new K-Ar data. Geologica Carpatica, 48, 353-359.

Roşu, E., Udubaşa, G., Pécskay, Z., Panaiotu, C., and Panaiotu, C.E. (2004) Timing of Miocene-Quaternary magmatism and metallogeny in the South Apuseni Mountains, Romania. In E. Rosu, Ed., Gold in the Metaliferi Mountains, 33-38. Romanian Journal of Mineral Deposits, Special Issue, 81.

Roşu, E., Seghedi, I., Downes, H., Alderton, D.H.M., Szakács, A., Pécskay, Z., Panaiotu, C., Panaiotu, C.E., and Nedelcu, L. (2005) Extension-related Miocene calc-alkaline magmatism in the Apuseni Mountains, Romania: origin of magmas. Schweizerische Mineralogische und Petrographische Mitteilungen, 84, 153-172.

Sintimbrean, A. (1989) Mining Museum from Roşia Montana, 219 p. Sport-Turism, București (in Romanian).

Soeda, A., Watanabe, M., Hoshino, K., and Nakashima, K. (1984) Mineralogy of tellurium-bearing canfieldite from the Tsumo mine, SW Japan and its implications for ore genesis. Neues Jahrbuch für Mineralogie-Abhandlungen, $150,11-23$.

Stadelmann, P. (1987) A software package for electron-diffraction analysis and HREM image simulation in materials science. Ultramicroscopy, 21, 131-145.

Tămaş, C.G. (2002) Breccia pipe structures related to hydrothermal ore deposits in Romania. Ph.D. thesis, University Babeş-Bolyai, Cluj-Napoca, Romania, 336 p. (in Romanian).

(2010) Endogenous breccia structures (breccia pipe - breccia dyke) and the petrometallogeny of Roşia Montana ore deposit (Metaliferi Mountains, Romania), 168 p., 2nd edition. Mega Publishing House, Cluj-Napoca (in Romanian).

Tămaş, C.G., and Bailly, L. (1998) Fluid inclusion study for Roșia Montana ore deposit. Romanian Journal of Mineral Deposits, 78, Suppl., 1, 97-98.

(1999) Rosia Montana low-sulfidation ore deposit - evidence from fluid inclusion study. Studia Universitatis Babeș-Bolyai, Geologia, XLIV/1, 49-56.

Tămaş, C.G., Bailly, L., Ghergari, L., O'Connor, G., and Minuț, A. (2004) First reported tellurides occurrence in Roșia Montana, Apuseni Mountains, Romania, 273. In $32^{\text {nd }}$ International Geological Congress, Florence, Italy, August 20-28, 2004. Abstract Volume.

(2006) New occurrence of tellurides and argyrodite at Roşia Montana, Apuseni Mountains, Romania and their metallogenetic significance. Canadian Mineralogist, 44, 689-705.

Tămas, C.G., Baron, S., and Cauuet, B. (2009) Mineralogy and lead isotope signature of gold-silver ores mined during Roman period in Alburnus Maior (Roşia Montana, Romania). ArcheoSciences-Revue d'Archéométrie 33, 83-90 (in French).

Uytenbogaardt, W., and Burke, E.A.J. (1971) Tables for Microscopic Identification of Ore Minerals, 430 p., 2nd revised edition. Elsevier, Amsterdam.

Williams, P.A., Hatert, F., Pasero, M., and Mills, S.J. (2012) New minerals and nomenclature modification approved in 2012. IMA Commission on New Minerals, Nomenclature and Classification (CNMNC), Newsletter 14. Mineralogical Magazine, 76(5), 1281-1288.

Wimmers, D. (1985) Silver minerals of Panasqueira, Portugal: a new occurrence of Te-bearing canfieldite. Mineralogical Magazine, 49, 745-748. 